\title{
Ungkapan Fatis Pada Dialog Dalam Buku Koala Kumal Karya Raditya Dika
}

\author{
Prapti Wigati Purwaningrum \\ ABA BSI Jakarta \\ Jl. Salemba Tengah no. 45 Jakarta Pusat \\ Email: prapti.pwp@bsi.ac.id
}

\begin{abstract}
The purposes of the analysis are to find the phatics categories and the function of it in the context of the dialog. The writer provides data from the dialog which consist of phatic categories then analyze it. The data of the analysis are taken from Koala Kumal book written by Raditya Dika. Phatic chategories by Kridalaksana, the function of language by Leech, Criteria of phatics by Jacobson are choosen as the theory in this analysis. Based on the analysis the writer found some categories and the function of phatics. Particle as the phatic category which is mostly found in Koala Kumal book. It has the function to convince the meaning of the statement. Phrases and words are also found in it such as terima kasih, apa kabar, assalamualaikum, wassalamualaikum, and halo. The function of Assalamualaikum, halo, apa kabar are to start the conversation. Besides that terima kasih and wassalamualakum as phrase annd words category of fatis are also used to end the conversation.
\end{abstract}

Key Word: speech situation, phatic categories, Koala Kumal Book Written By Raditya Dika

\section{PENDAHULUAN}

Perkembangan teknologi saat ini sudah semakin canggih, berbagai informasi dan hiburan dapat diperoleh melalui akses internet. Mereka tidak perlu beranjak kemana-mana hanya dengan sentuhan jari segala informasi dapat mereka dapati. Begitupun dengan perkembangan aplikasi yang semakin melengkapi handphone juga semakin beragam, misalnya untuk yang memiliki hobi membaca novel kini tidak perlu harus merogoh kantong untuk mendapatkan buku atau novel yang mereka inginkan, namun hanya dengan mengunduh aplikasi wattpad berbagai macam genre buku atau novel dapat dinikmati.

Novel dan juga buku kumpulan cerita merupakan bagian dari karya sastra yang masih menjadi primadona di masyarakat saat ini. Melalui sentuhan kreatif sang penulis tidak jarang pembaca larut dalam alur cerita yang mungkin sedih, senang, romantis, lucu, mencekam, dan bahkan terkadang merasa ikut berpetualang dalam cerita tersebut. Meskipun novel maupun buku cerita sudah dapat dinikmati melalui daring, namun tidak mengurangi peminat untuk tetap membaca novel dalam versi cetak atau laring dengan berbagai alasan melatarbelakngi hal tersebut.

Salah satu buku yang cukup menarik perhatian saya kali ini merupakan terbitan dari gagas media yang bergenre komedi karya dari penulis muda yang terkenal dengan kejombloannya yaitu Raditya Dika. Dengan cerita kejombloannya ini justru yang telah menghantarkan dia menjadi seorang komika dan penulis terkenal. Sejak buku pertamanya yang berjudul kambing jantan, radikus makankakus, cinta brontosaurus, babi ngesot, manusia setengah salmon, marmut merah jambu yang semua bukunya menceritakan tentang saat menjadi mahasiswa, jatuh cinta, hingga patah hati. Kata-kata dalam buku ini ringan, mudah dipahami dan lucu hingga mampu membuat pembaca tertawa geli dengan kepolosan dan kejombloan tokoh utamanya yaitu dika yang tidak lain adalah penulis buku tersebut.

Dialog antar karakter dalam buku ini tidak jarang mengundang tawa dan kegelian. Dialog yang digunakan sangat sederhana dan mudah diterima oleh pembaca. Selain itu hampir dalam setiap dialog banyak sekali ditemukan ungkapan yang berupa partikel, kata dan frasa seperti nih, dong, sih, kok, lho, ya, kek, yah, toh, kan, halo, terima kasih yang sepintas tidak terlalu penting dalam dialog namun jika diamati lebih mendalam ternyata ungkapan tersebut memiliki maksud tertentu dalam tiap dialog yang dituturkan oleh penuturnya. Beberapa ungkapan tersebut dikenal dengan ungkapan fatis.

Menurut (Kridalaksana, 1999) ungkapan atau kategori fatis merupakan kategori yang bertugas untuk memulai, mempertahankan, dan menekankan komunikasi antar penutur dan petutur. Ungkapan atau kategori fatis ini merupakan bagian dari fungsi bahasa yang sangat sering ditemukan terutama dalam ragam bahasa lisan. Ahli lain juga menyebutkan bahwa fungsi fatis dari suatu bahasa adalah untuk menjaga hubungan sosial secara baik dan menjaga agar komunikasi tetap berkesinambungan Leech (1977: 47-50).

Dalam tulisan ini penulis tertarik untuk memilih buku dari Raditya Dika dengan judul Koala Kumal. Pada bukunya kali ini Dika sapaan akrabnya menceritakan kisahnya dari saat dia masih SD yang digambarkan sebagai sosok yang tidak terlalu memiliki banyak teman dan main game sebagai hobinya, lalu beranjak dewasa sebagai sosok yang cukup pendiam serta lika liku cintanya dengan beberapa cewe aneh hingga merasakan sakitnya 
ditolak. Cerita tidak berhenti sampai disitu hingga akhirnya dika menemukan sosok cewe yang bisa mengubah statusnya dari jomblo menjadi memiliki pacar meskipun akhirnya berakhir dengan Long Distance Relationship (LDR) karena munculnya orang ketiga. Alur cerita ini memberikan arti tersendiri bagi perjalanan kehidupannya, yang juga merupakan sebuah nasehat dari sang mamah bahwa orang yang sudah pernah merasakan patah hati merupakan orang yang "Dewasa”.

Dalam buku ini pada beberapa dialog banyak sekali ditemukan ungkapan atau kategori fatis oleh karena itu penulis tertarik untuk mengamati serta menganalisa bagaimana dan untuk tujuan apa para karakter dalam cerita koala kumal karya Raditya Dika tersebut sering menggunakan ungkapan atau kategori fatis pada dialognya.

Tinjauan Pustaka

Pragmatik

Menurut Leech (1983) berpendapat bahwa pragmatik adalah ilmu tentang maksud hubungannya dengan situasi-situasi (speech situation). Proses tindak tutur ditentukan oleh konteks yang menyertai sebuah tuturan.

\section{Aspek Tutur}

Menurut Leech, Aspek Tutur meliputi penutur, lawan tutur, tujuan tutur, tuturan sebagai produk tindak verbal. Terkait dengan aspek tutur penutur dan lawan tutur ditegaskan bahwa lawan tutur atau petutur adalah orang yang menjadi sasaran tuturan dari penutur.

Menurut Hymes (1972) di dalam peristiwa tutur ada yang menandai keberadaan peristiwa itu. Setting atau tempat adalah suasana peristiwa tutur, Participants adalah penutur, petutur dan pihak lain, ends atau tujuan yaitu tujuan tuturan tersebut dituturkan, acts yaitu tindakan yang dilakukan oleh penutur di dalam peristiwa tutur, key yaitu nada suara atau ragam bahasa yang digunakan di dalam mengekspresikan tuturan dan cirri mengekspresikannya, Instrument merupakan alat yang digunakan pada saat penutur menuturkan tuturannya, Norms atau Norma adalah aturan yang harus dipatuhi oleh semua peserta tutur, dan yang terakhir adalah Genre adalah jenis kegiatan atau peristiwa itu sendiri.

Leech (1977:47-50), membagi fungsi bahasa menjadi lima. Yang pertama adalah fungsi informatif, yaitu bahasa yang berfungsi sebagai alat untuk menyampaikan informasi. Kedua adalah fungsi ekspresif. Fungsi ekspresif bahasa dipakai untuk mengungkapkan perasaan dan sikap penuturnya, Jika dalam fungsi informatif yang dipentingkan makna konseptual, dalam fungsi ekspresif yang dipentingkan makna afektif. Ketiga adalah fungsi direktif, yaitu jika bahasa yang kita gunakan bertujuan untuk mempengaruhi perilaku atau sikap orang lain seperti dalam ujaran yang berupa perintah dan permohonan. Keempat adalah fungsi estetis bahasa, yaitu penggunaan bahasa berkaitan dengan karya seni. Kelima adalah fungsi fatis, yaitu fungsi bahasa yang digunakan untuk menjaga hubungan sosial secara baik dan menjaga agar komunikasi tetap berkesinambungan.

\section{Ungkapan fatis}

Menurut Kridalaksana (2005:114), ungkapan fatis merupakan ungkapan yang mengandung kategori fatis yang bertugas untuk memulai, mempertahankan, mengukuhkan pembicaraan antara pembicara dan kawan bicara. Beliau juga mengungkapkan kategori fatis merupakan ciri ragam lisan yang nonstandar sehingga kebanyakan kategori fatis terdapat dalam kalimat-kalimat nonstandar. Kridalaksana membagi kategori fatis menjadi tiga bagian dalam tuturan atau kalimat yang memungkinkan munculnya ungkapan fatis, yaitu pada awal, tengah, dan akhir kalimat.

\section{Kategori fatis}

Kridalaksana dalam Sutami (2005:116-120) juga mengungkapkan pembagian kategori fatis yaitu partikel fatis, kata fatis, serta frasa fatis. Ungkapan fatis meliputi ah, ayo, deh, dong, ding, halo, kan, kek, kok, lah, lho, mari, pun, selamat, sih, toh, tau, ya, yah, selamat, terima kasih, turut berduka cita, alhamdulilah, insya allah, assalamualaikum, wa'alaikumsalam. Partikel dan kata fatis merupakan kategori yang paling banyak, partikel fatis meliputi ah, deh, ding, dong, kan, kek, kok, -lah, loh, nah, pun, sih, toh, ya, dan yah. Sedangkan pada kata fatis mencakup halo, selamat, ayo, dan mari. Kategori yang kedua adalah frasa fatis terdiri dari (selamat pagi, siang, sore, malam, belajar dll), terima kasih, turut berdukacita, assalamualaikum, wa'alaikumsalam, insya allah, dengan hormat, hormat saya.

Kriteria kefatisan menurut Jacobson (1980) adalah:

1. Memulai komunikasi

2. Mempertahankan atau mengukuhkan komunikasi

3. Memutuskan komunikasi

4. Memastikan berfungsinya saluran komunikasi

5. Menarik perhatian kawan bicara atau menjaga agar kawan bicara tetap memperhatikan pembicara.

Kriteria kefatisan menurut Leech

1. Menjaga hubungan sosial agar tetap baik, diantaranya dengan basa basi yang tidak membutuhkan jawaban atau tanggapan sesuai dengan isi ujaran

2. Menjaga agar komunikasi tetap berkesinambungan. 
Dari kedua ahli tersebut di atas, jelas bahwa kriteria kefatisan sama-sama memiliki tujuan sosial yaitu agar hubungan antara petutur dan mitra tutur tetap terjaga, sehingga hubungan kedekatan dari masingmasing pihak dapat terwujud.

\section{Fungsi Kategori Fatis}

Menurut Kridalaksana (2005:116-119) bahwa setiap kategori fatis berupa partikel, kata maupun frasa yang muncul dalam lisan dan tulisan nonstandar memiliki tujuan atau tugas yang berbeda-beda.

Berikut fungsi-fungsi Partikel dan kata fatis:

1. Fatis nah memiliki tugas untuk meminta mitra tutur mengalihkan perhatian ke yang lain

2. Fatis deh memiliki tugas untuk mengungkapkan pemaksaan dengan membujuk, memberi persetujuan, garansi, serta penekanan

3. Fatis kan bertugas untuk menekankan pada pembuktian dan dapat juga sebagai pembantahan

4. Fatis kok memberikan makna penekanan dan pembantahan, pengingkaran atau sebagai pengganti kata tanya mengapa atau kenapa.

5. Fatis sih memiliki tugas untuk menunjukan maksud yang berarti memang atau sebenarnya, menekankan atau memperkuat alasan,

6. Fatis dong bertugas untuk menekankan pertanyaan, menghaluskan perintah, menekankan kesalahan mitra tutur,

7. Fatis ding mengungkapkan pengakuan kesalahan penutur

8. Fatis kek bertugas untuk menekankan harapan atau keinginan, perincian, perintah.

9. Fatis nih bertugas untuk menekankan atau menguatkan pernyataan.

10. Fatis ah digunakan untuk menekankan rasa penolakan atau acuh tak acuh terhadap sesuatu dan selain itu dapat juga digunakan sebagai penegaskan terhadap sesuatu yang dilakukan.

11. Fatis Lho atau loh Menekankan kepastian.

12. Fatis $Y a$ atau yak jika letaknya di awal kalimat maka bertugas untuk mengukuhkan atau membenarkan tuturan dari mitra tutur. Meminta persetujuan atau pendapat mitra tutur jika posisinya di akhir kalimat.

13. Fatis yah untuk mengungkapkan perasaan simpatik dan dapat juga mengungkapkan rasa kekecewaan dan keraguan terhadap sesuatu.

14. Fatis toh memiliki tugas untuk mengungkapkan menguatkan maksud atau keinginan yang ingin dilakukan oleh si penutur.

15. Fatis halo bertugas untuk mengukuhkan pembicaraan di telepon dan menyalami mitra tutur yang dianggap dekat.

16. Fatis selamat untuk memberi selamat pada mitra tutur

17. Fatis mari untuk menekankan ajakan
Berikut fungsi-fungsi frasa fatis:

1. Selamat malam, selamat jalan digunakan untuk memulai dan mengakhiri percakapan sesuai situasi dan keperluannya.

2. Terima kasih digunakan setelah pembicara merasa mendapat sesuatu dari lawan bicara

3. Turut berduka cita digunakan untuk mengungkapkan rasa duka cita

4. Assalamualaikum digunakan pada waktu pembicara ingin memulai interaksi.

5. Waalaikumsalam digunakan untuk menjawab kawan bicara yang menuturkan assalamualaikum

6. Insya Allah dituturkan apabila pembicara menerima tawaran untuk melakukan sesuatu dari kawan bicara.

\section{METODOLOGI PENELITIAN}

Pendekatan Penelitian

Pendekatan yang digunakan dalam penelitian ini adalah kualitatif. Metode penelitian yang digunakan adalah analisis isi karena penelitian ini lebih mengutamakan pendekatan konten dari dialog dalam buku tersebut. Penulis memilih buku dengan judul Koala Kumal karya Raditya Dika karena di dalamnya banyak sekali ungkapan atau kategori fatis yang terkadang menimbulkan implikasi yang berbeda-beda. Data penelitian berupa penggalan dialog dalam buku tersebut.

Menurut Sudaryanto (2015:11-13) dalam sebuah penelitian penggunaan istilah penyediaan data dan analisis data dirasa lebih sesuai, tepat, mengena dan menghindari kesan yang terlalu indrawi. Istilah penyediaan cukup eksplisit menunjukan tujuan, mewakili istilah pengumpulan, pemilihan, dan penataan. Selain itu dengan istilah Penyediaan tersarankan adanya tahap lanjutan untuk pemecahan masalah yaitu analisis.

\section{Proses Penyediaan Data}

Penyediaan data dilakukan dengan membaca buku Koala Kumal, mengidentifikasi dialog yang mengandun ungkapan fatis, lalu mengelompokannya berdasarkan kategorinya yaitu partikel, kata, atau frasa. Penulis membutuhkan waktu sekitar 3 minggu untuk menyediakan data berupa dialog yang terdapat ungkapan atau kategori fatis.

\section{Analisis Data}

Data yang sudah tersedia merupakan penggalan dialog dari buku Koala Kumal karya Raditya Dika yang berisi ungkapan atau kategori fatis. Penulis mengamati, mengidentifikasi kategori fatis lalu mengelompokannya berdasarkan kategori yaitu partikel, kata, dan frasa. Setelah seluruh data teridentifikasi langkah selanjutnya adalah penulis menganalisis data tersebut dengan menggunakan teori dari Kridalaksana untuk mengetahui apakah kategori fatis yang muncul memiliki tugas memulai, 
mempertahankan, atau mengukuhkan suatu maksud dari si penutur dan petutur dalam dialog tersebut.

\section{HASIL DAN PEMBAHASAN}

Beberapa kategori fatis yang ditemukan dalam buku Koala Kumal dari Raditya Dika, penulis akan menganalisis ketegori fatis yang ditemukan dalam cerita tersebut untuk mengetahui tugas dan maksud penutur menggunakan kategori fatis tersebut dalam tuturan pada dialog tersebut. Dalam menganalisis data, penulis menggunakan teori dari Kridalaksana (2005:116) dan Leech (1977)

\section{Menekankan Kepastian}

Loh, kan, dan dong Data 88 ( Dika dan sang pacar sedang membicarakan hal yang serius tentang hubungan mereka yang akan mereka jalani. LDR merupakan keputusan yang akhirnya mereka pilih setelah Dika memilih untuk melanjutkan pendidikannya ke Ausie selama kurang lebih 4 tahun. Mereka sama-sama merasa apakah mereka mampu untuk menjalaninya, sepertinya pacarnya mulai ragu tentang LDR ini setelah membaca sebuat situs di internet tentang sepersekian persen LDR akan gagal.

Pacar : aku baca di website mana gitu, katanya pasangan LDR ga bakal berhasil Loh

Dika : Tapi Indonesia-Ausie kan ga jauh-jauh amat, beda waktunya juga yah 4 jam.

Pacar : Kamu emang percaya kita bakal bisa LDR?

Dika : Yah, kita harus percaya dong.

Dalam dialog di atas pacar Dika mencoba meluapkan kekhawatirannya mengena LDR yang akan dijalaninya. Dalam penggalan dialog di atas pacar dika bertutur "aku baca di website mana gitu, katanya pasangan LDR ga bakal berhasil Loh' melalui tuturan ini terlihat bahwa pacarnya berusaha mengungkapkan sebuah bukti yang mungkin akan bisa mendukung atas sikap keraguannya terhadap LDR. Dika berusaha untuk meredam kehawatiran tersebut dengan juga memberikan bukti bahwa meskipun LDR tetapi hanya hanya terpaut 4 jam dalam perbedaan waktu, itu akan baik-baik saja. Namun keraguan itu masih tetap membayangi sang pacar dengan kembali bertutur "Kamu emang percaya kita bakal bisa LDR?” Dika pun mencoba menepis kembali keraguan oyang sedang melanda orang terkasihnya, meskipun tuturanyapun mengisyaratkan keraguan "Yah, kita harus percaya dong"

Dalam tuturan sang pacar "aku baca di website mana gitu, katanya pasangan LDR ga bakal berhasil Loh”. Terdapat kategori fatis jenis partikel yaitu Loh yang memiliki tugas untuk menekankan sebuah kepastian. Dalam hal ini ada sebuah keraguan dalam benak pacar Dika, dengan demikian dalam tuturannya Loh menyiratkan bahwa dia mengharap Dika untuk meyakinkan akan sebuah kepastian bahwa apa yang dia baca tentang LDR tidak akan terjadi pada hubungan mereka. Disini Dika mencoba meyakinkan sang pacar dengan tuturannya "Tapi Indonesia-Ausie kan ga jauh-jauh amat, beda waktunya juga yah 4 jam” di dalamnya juga terdapat ungkapan fatis kan yang bertugas menekankan pembuktian yaitu meski terpisah jarak namun hanya mengalami perbedaan waktu 4 jam, semua akan baik-baik saja. Sang pacar kembali bertutur "kamu emang percaya kita bakal bisa LDR?” saat itu sebenarnya Dikapun sangat berat untuk menghadapi serta menjalani LDR, namun dia tetap berusaha bersikap tenang dan bijak, bahwa semua itu akan bisa dilalui jika diawali dari dasar hati yaitu keyakinan dan percaya jika kita bisa lalui semua. Dika berusaha meyakinkan pacar untuk yakin dan percaya bahwa LDR bisa baik-baik saja. Hal ini terlihat pada tuturan Dika "Yah, kita harus percaya dong". Ungkapan fatis dong bertugas untuk menghaluskan perintah, pada tuturan tersebut secara halus Dika menyuruh pacarnya untuk berusaha bersikap percaya tenang dalam menjalani LDR.

Menunjukan maksud yang berarti memang atau sebenarnya, pengganti kata tanya kenapa, penekanan terhadap sesuatu, Menyatakan keraguan tentang sesuatu.

Sih,kok, deh, yah Data 91 (saat Dika di rumah pacar untuk berpamitan bahwa keesokan harinya dia harus berangkat ke Ausie untuk melanjutkan pendidikannya. Ada kesedihan serta keraguan yang tergambar jelas di wajah pacarnya).

Dika : kamu kenapa sih kok ga kayak biasanya?

Pacar : Aku takut deh

Dika : Takut kenapa?

Pacar : nanti kalau kamu disana ketemu orang lain gimana?

Dika : Ketemu siapa?

Pacar : iya, siapa tau disana ada cewe pirang naksir kamu?

Dika : ya ampun, aku kalau mau ngobrol sama orang asing aja harus jinjit, gimana mau pacaran?

Pacar : yah siapa tau ada cewe pirang cantik pendek yang mau sama kamu.

Dalam dialog di atas Dika dan pacarnya sedang membicarakan tentang hubungan LDR yang pasti akan mereka lalui. Dika akan melanjutkan pendidikannya di Ausi selama kurang lebih 4 tahun. Pacarnya mulai ragu akan hal tersebut, bahkan sempat berpikir bagaimana jika suatu saat Dika bertemu seseorang disana. Percakapan mereka diawali dengan tuturan "kamu kenapa sih kok ga kayak biasanya?" tuturan ini dituturkan Dika karena melihat sikap pacarnya yang sedikit berbeda dari biasanya, kecurigaan Dikapun terjawab, ternyata pacarnya merasa cemas atau taku akan kepergian Dika ke Ausie, hal ini terlihat pada tuturan "aku 
takut deh" jika suatu saat Dika bertemu seseorang disana dan mereka saling menyukai. Namun Dika berusaha menenangkan perasaan pacarnya dengan bertutur "ya ampun, aku kalau mau ngobrol sama orang asing aja harus jinjit, gimana mau pacaran? Sambil tersenyum untuk menenangkan pacarnya.

Tuturan yang mengandung ungkapan atau kategori fatis terdapat pada tuturan "kamu kenapa sih kok ga kayak biasanya?.” Keduanya merupakan kategori fatis jenis partikel sih bertugas untuk menunjukan maksud memang atau sebenarnya tentang suatu hal atau kondisi dan Kok bertugas untuk menggantikan kenapa atau mengapa. "kamu kenapa sih kok ga kayak biasanya?” tuturan tersebut menyiratkan keingintahuan kebenaran atas sikap pacarnya seperti itu ditandai dengan munculnya ungkapan fatis sih serta diikuti oleh ungkapan fatis kok yang bertugas menggantikan kata kenapa atau mengapa. Dika berusaha mencari tahu kebenaran serta alasan atas sikap pacaranya. Pertanyaanya terjawab dengan "aku takut deh” ternyata pacarnya merasa takut jika suatu hari di Ausie Dika bertemu dengan sosok lain yang mampu memikatnya dengan bertutur "iya, siapa tau disana ada cewe pirang naksir kamu?” namun segera dibantah oleh Dika dengan tuturan ya ampun, aku kalau mau ngobrol sama orang asing aja harus jinjit, gimana mau pacaran? Tuturan tersebut langsung dijawab oleh pacarnya "yah siapa tau ada cewe pirang cantik pendek yang mau sama kamu”. Dari tuturan tersebut terdapat ungkapan fatis yah yang bertugas menyatakan keraguan akan sesuatu hal. Meskipun pacarnya bertutur demikian namun tuturan tersebuh tersirat jauh di lubuk hatinya sebuah keraguan tentang ada cewe pirang atau bule pendek dan naksir Dika.

Menyuruh mitra tutur unutk mengalihkan perhatian atau ke topik lain

Nah Data 22: Saat itu Dika dan kirana sedang asyik menonton pertandingan sepak bola di Televisi. Namun tiba-tiba kiran memecah konsentrasi Dika dengan melontarkan sebuah pertanyaan yang cukup membuat Dika terganggu.

$\begin{array}{ll}\text { Kirana } & \text { : Kalo kartu kuning artinya apa? } \\ \text { Dika } & \text { : Oh, kalo itu artinya pelanggaran } \\ \text { Kirana } & \text { : jadi kalo pelanggaran, wasitnya ngasih } \\ & \text { kartu kuning ke pemainnya? } \\ \text { Dika } & \text { : Iya } \\ \text { Kirana } & \text { : Kok kartunya ga habis kalo dikasih-kasih } \\ \text { gitu? } & \text { : kartunya ga beneran dikasih, tapi dikasih } \\ \text { Dika } & \begin{array}{l}\text { liat doang trus dikantongi lagi. Nah } \\ \text { offside itu kayak yang barusan. }\end{array} \\ \text { Kirana } & \text { Oh, ngerti sekarang. Sekarang skor } \\ & \text { berapa? }\end{array}$

Saat itu Dika dan kirana sedang asik menonton pertandingan sepak bola di televisi. Namun saat asyik memperhatikan pertandingan, tiba-tiba terdengar suara kirana yang bertutur "Kalo kartu kuning artinya apa?” Saat itu wasit terlihat memberikan kartu kuning sebagai peringatan pada salah satu pemain yang dianggap telah melakukan pelanggaran. Dika segera menjawabnya dengan bertutur "Oh, kalo itu artinya pelanggaran”. Ternyata keingintahuan kirana tidak berhenti sampai disitu dia kembali bertutur "jadi kalo pelanggaran, wasitnya ngasih kartu kuning ke pemainnya?” dan dijawab singkat oleh Dika "Iya" ternyata pertanyaan kirana berlanjut dengan menuturkan Kok kartunya ga habis kalo dikasih-kasih gitu?. Dika mulai kesal dengan beberapa pertanyaan kirana. Akhirnya Dika tetap mencoba menjawab "kartunya ga beneran dikasih, tapi dikasih liat doang trus dikantongi lagi. Nah offside itu kayak yang barusan”. Diakhir jawabannya Dika mencoba memberikan pernyataan yang berbeda dengan topik pembicaraan sebelumnya yaitu “Nah offside itu kayak yang barusan”. Namun pernyataan tersebut tidak terlalu ditanggapi kirana yang sebelumnya membahas tentang kartu kuning.

Ungkapan fatis jenis partikel Nah ditemukan pada tuturan Dika di atas. Partikel Nah memiliki tugas untuk menyuruh mitra tutur mengalihkan perhatian melalui tuturan maupun topik pembicaraan. Dalam tuturan "Nah offside itu kayak yang barusan" partikel Nah memiliki tugas untuk menyuruh mitra tutur yaitu kirana untuk mengalihkan perhatiannya tentang pertanyaan kartu kuning yang menurut Dika hal tersebut tidak terlalu penting untuk terus dipertanyakan. Hal ini terlihat dari tuturan kirana “Kok kartunya ga habis kalo dikasih-kasih gitu?”. Lalu Dika mencoba menjelaskan dan mengalihkan perhatian Kirana dengan bertutur "Nah offside itu kayak yang barusan”. Maksud Dika disini agar Kirana tidak lagi bertanya tentang kartu kuning yang sebenarnya apapun penjelasan yang diberikan Dika tidak akan membuat Kirana memahaminya. Hal ini terlihat dari jawaban Kirana "Oh, ngerti sekarang, Sekarang skor berapa?”, dari tuturan “oh ngerti sekarang” merupakan respon Kirana yang sama sekali tidak ada hubungannya dengan pertanyaan dia sebelumnya yaitu tentang kartu kuning, namun saat disebutkan tentang contoh offside Kirana bertutur "oh ngerti sekarang" dan lanjut bertanya tentang skor. Dika merasa sia-sia memberikan respon dan penjelasannya pada Kirana tentang kartu kuning. Hal ini terlihat dari tingkah Dika yang menepok jidatnya yang menandakan dia sedikit kesal pada ulah Kirana yang sempat mengganggu konsetrasi Dika dengan beberapa pertanyaan.

Menekankan atau menguatkan pernyataan, menekankan pertanyaan

Nih, dong Data 101: siang itu Mirzan dan Dika bertemu setelah sekian lama sibuk dengan urusan mereka masing-masing. Mereka berbincang dan saling bertukar cerita termasuk kisah cinta dan kejombloannya. 


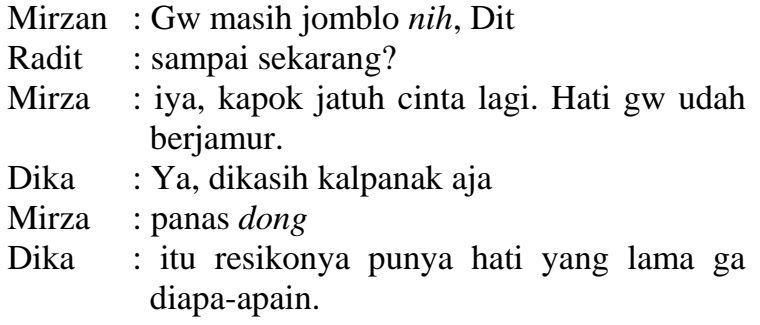

Berdasarkan dialog diatas antara Dika dan Mirzan yang telah lama tidak bertemu. Mereka saling bertukar cerita tentang apa yang telah mereka lalui selama tidak bertemu. Sejak Mirza mengalami kekecewaan dalam sebuah hubungan sampai saat itu Mirza belum kembali membuka hatinya untuk sebuah nama baru, sehingga dia masih nyaman dengan kejombloannya. Hal ini terlihat dari tuturan Mirza "Gw masih jomblo nih, Dit" seolah ingin memberitahukan pada Dika bahwa sejak kejadian beberapa tahun yang lalu masih lekat hingga sekarang. Dika segera memberi respon atas pernyataan Mirza dengan bertutur "sampai sekarang?” langsung dijawab “iya, kapok jatuh cinta lagi”, Hati gw udah berjamur”. Mirza seakan sudah tidak ingin membina sebuah hubungan karena kekecewaan di masa lalu. Namun ternyata Dika menanggapinya dengan candaan konyolnya dengan bertutur "ya dikasih kalpanak aja", dia mengibaratkan hati Mirzan yang sudah berjamur layaknya seperti kulit jadi harus diberi kalpanak biar jamurnya hilang. Mirzapun tak kalah konyol, dia menanggapi keusilan Mirza dengan bertutur "panas dong?” Dika seolah serius menanggapinya dengan bijak meskipun sebenarnya konyol dengan mengibaratkan hati Mirza yang sudah lama kosong dari nama cewe sebagai sebuah benda yang yang sudah lama tidak digunakan maka akan jamuran, tuturan ini terlihat pada respon Dika "itu resikonya punya hati yang lama ga diapa-apain”.

Kategori fatis yang muncul pada tuturan di atas adalah nih dan dong. Nih bertugas untuk menguatkan pernyataan dan dong digunakan untuk menekankan pertanyaan. Pada tuturan "Gw masih jomblo nih, Dit” ungkapan fatis Nih memberikan penguatan pada pernyataan Mirzan tentang statusnya yang masih jomblo, hal ini didukung juga dengan pernyataan Mirzan berikutnya "iya, kapok jatuh cinta lagi”, Hati gw udah berjamur”. Tuturan tersebut mendukung sekaligus memberikan alasan sebagai bukti atas pernyataan Mirza sebelumnya tentang status jomblonya. Ungkapan fatis dalam tuturan Mirzan berikutnya “panas dong?” ungkapan fatis ini digunakan untuk menekankan pertanyaan Mirzan atas pernyataan Dika "ya, dikasih kalpanak aja” hal ini dilatarbelakangi sebuah pengetahuan bahwa kalpanak merupakan obat kulit yang berjamur yang jika digunakan akan menimbulkan rasa panas. Dong memberikan penekanan pertanyaan, karena dalam hal ini yang berjamur adalah hati Mirzan dan kenyataanya tidak benarbenar berjamur namun hati itu hampa karena sudah lama tidak menyimpan sebuah nama istimewa di dalamnya. Oleh karena itu penekanan pertanyaan hanya candaan apakah benar hati Mirzan harus dikalpanak.

Menekankan pada pembuktian

Kan Data 95 (Dika dan pacarnya sudah menjalani LDR selama 2 tahun, seiring berjalanya waktu komunikasi keduanya tidak seintent atau seefektif dulu lagi. Banyak hal yang membuat mereka semakin jarang berkomunikasi. Hingga suatu saat timbul rasa yang lain di benak pacarnya untuk mengambil sebuah keputusan.

Pacar : kamu ngrasa ga sih? Kalo kita udah ga seintensif dulu ?

Dika : iya sih. Akhir-akhir ini komunikasi kita ga selancar dulu

Pacar : aku mau ngomong sesuatu sama kamu.

Dika : apa?

Pacar : gimana ya, bingung ngomongnya.

Dika : mau ngomong apa sih?

Pacar : Jadi gini......

Dika : kok aku jadi deg degan ya?

Pacar : Gini kita kan udah lama pacaran.

Dika : terus?

Pacar : tapi ada hal yang harus kamu tahu....

Dika : kamu kenapa sih?nanti aku beneran deg degan nih

Pacar : aku ketemu orang lain. Tapi kamu masih yang terbaik buat aku kok.

Pada dialog di atas menceritakan tentang hubungan Dika dan pacarnya, yang saat itu mereka jalani secara LDR. Dika melanjutkan pendidikan di Auise selama 4 tahun, awalnya mereka menjalani LDR baik-baik saja. Setelah dua tahun berlalu ada perubahan yang terjadi, komunikasi mereka tidak seintensif dulu lagi. Suatu hari sang pacar menelpon Dika untuk menyampaikan sesuatu tentang hubungan mereka. Hal ini terlihat pada tuturan pacar "kamu ngrasa ga sih? Kalo kita udah ga seintensif dulu?” kemudian direspon oleh Dika seolah membenarkan tuturan pacaranya "iya sih. Akhir-akhir ini komunikasi kita ga selancar dulu”. Pembicaraan mereka masih berlanjut hingga tibatiba ada tuturan pacarnya yang cukup membuat Dika cemas, "Gini kita kan udah lama pacaran” dengan tenang Dika menjawab “terus?” lama Dika menunggu apa yang sebenarnya ingin pacaranya ungkapkan. Akhirnya Dika mendengar tentang apa yang ingin disampaikan "aku ketemu orang lain”. Dika sejenak terdiam mencoba memahami maksud tuturan pacarnya. Ternyata hubungan mereka harus berakhir di tahun kedua. Dika tidak mampu berkata apa-apa lagi keputusan sudah diambil pacaranya karena dia telah menemukan sosok lain yang mampu menggantikan Dika. Lalu percakapan mereka 
berakhir seiring dengan berakhirnya hubungan mereka.

Kategori fatis pada dialog diatas kan memiliki tugas untuk menekankan pada pembuktian tentang ssesuatu hal. Dalam tuturan "Gini kita kan udah lama pacaran” dengan menggunakan partikel kan pacar Dika berusaha meyakinkan dan membuktikan untuk memperkuat bahwa hubungan mereka memang sudah lama. Pembuktian itu dilakukan untuk semakin meyakinkan bahwa dengan LDR yang sudah dua tahun ternyata tidak menjamin kelangsungan sebuah hubungan, komunikasi mereka semakin menurun, dengan alasan seperti itu akan sangat membantu si pacar untuk membuktikan bahwa hubungan tersebut sudah tidak sehat. Dengan alasan demikian maka tepat bagi pacar Dika untuk meminta putus atau mengakhiri LDR mereka. Menekankan harapan atau keinginan

Kek Data 79: Pada pertemuan antara Trisna dan Dika yang telah sekian lama tidak bertemu karena Trisna harus tinggal di Bali karena terikat pekerjaan yang mengharuskan dia tinggal disana. Dalam pertemuan itu mereka kembali bernostalgia dengan kenangan mereka masing-masing, terutama Trisna yang bercerita tentang kisah cintanya dengan Ruben.

Trisna : gue pengen masuk UGM juga. Gw berpikiran kalo gw kuliah di Jogja tiap pagi ke kampus bareng, ngekos deketan, weekend gue sama dia jalan-jalan keliling kota joga, jalan berdua, pegangan tangan di depan tugu pahlawan.

Dika : Bentar Tris tugu pahlawan itu adanya di Surabaya.

Trisna : Ya, udah apa kek yang ada di Jogja.

Percakapan di atas terjadi antara Trisna dan Dika. Trisna menceritakan tentang cerita cintanya bersama Ruben, hubungannya sudah cukup lama. Saat menjelang ujian akhir sekolah, mereka sama-sama memiliki keinginan untuk dapat kuliah di UGM Jogja. Keduanya sama-sama diterima sebagai mahasiswa di kampus ternama tersebut. Trisna memiliki keinginan jika nanti di Jogja mereka akan selalu bersama, berangkat dan pulang bareng, kost berdekatan, menghabiskan akhir pekan dengan jalan-jalan di Jogja seperti pada tuturan "gue pengen masuk UGM juga. Gw berpikiran kalo gw kuliah di Jogja tiap pagi ke kampus bareng, ngekos deketan, weekend gue sama dia jalan-jalan keliling kota joga, jalan berdua, pegangan tangan di depan tugu pahlawan”. Namun takdir berkata lain, Ruben meninggal dalam sebuah kecelakaan saat dia akan mencari kado untuk perayaan kelulusan Trisna diterima di UGM.

Ungkapan fatis yang ada pada penggalan dialog berikut adalah masuk ke dalam kategori partikel yaitu Kek. Ungkapan fatis ini bertugas untuk menekankan harapan atau keinginan, pada tuturan Trisna "Ya, udah apa kek yang ada di Jogja". Tuturan ini dituturkan saat sebelumnya Trisna menyatakan bahwa tugu pahlawan di Jogja dan Dika mencoba mengingatkan dengan bertutur "Bentar Tris tugu pahlawan itu adanya di Surabaya”. Dalam tuturan Trisna menggunakan kategori fatis kek menyatakan harapan Trisna untuk bisa bersama dengan Ruben, jika tugu muda salah berada di Jogja, apapun itu yang penting harapannya bisa terwujud untuk bisa selalu bersama di kota Jogja itu.

Membuka pembicaraan atau komunikasi, penekanan terhadap sesuatu

Apa kabar, Deh Data 102: Saat Dika dan mantan bertemu kembali, mereka menyempatkan mengobrol bersama di sebuah cafe. Dika yang saat itu masih jomblo sejak putus dari cewe yang saat ini ada di hadapannya, sedangkan sang manta sudah memiliki kekasih baru.

Dika : apa kabar?

Mantan : Baik. Nomor kamu ganti?

Dika : iya

Mantan : aku kayaknya salah deh jadian sama dia

Dika : maksud kamu?

Mantan : aku nyesel.

Dika : maksudnya nyesel?

Mantan : engga...ngga appa-apa.

Cafe menjadi tempat pilihan mereka untuk ngobrol setelah sekian lama mereka tidak bertemu. Beberapa tahun yang lalu cewe yang sekarang telah menjadi mantan telah menghianati Dika dengan cara berselingkuh. Namun meskipun telah menjadi mantan ternyata mereka tetap bisa berkomunikasi dengan baik, tidak ada dendam meski ada sedikit canggung. Saat mereka bertemu Dika mencoba untuk bersikap tenang seolah tidak pernah terjadi hal yang menyakitkan, Dika mencoba mengawali komunikasi dengan tuturan “apa kabar?”, karena mungkin frasa itu yang paling cocok saat itu sekedar memulai percakapan. Begitupun dengan sang mantan tidak ingin terlihat gugup maka jawaban "baik" menjadi kata yang paling mudah untuk dijadikan sebagai jawaban. Setelah beberapa menit berlalu tiba-tiba mantan bertutur "aku kayaknya salah deh jadian sama dia”. Sedikit membuat Dika gugup dan kaget lalu dia bertanya untuk memastikan tentang tuturan yang baru saja dia dengar "maksud kamu?”. Sang mantan seolah ingin memperjelas tuturannya tentang rasa bersalah karena telah menghianati Dika "aku menyesal" dengan tuturan yang sedikit tertahan kembali membuat Dika bertanya "maksudnya nyesel?" namun sang mantan seolah tersadar bahwa tuturannya telah membuat Dika bertanya-tanya. Ternyata sang mantan ingin cepat mengakhiri topik tersebut dengan menjawab “engga...ngga apa-apa”. 
Pada penggalan dialog di atas terdapat dua kategori fatis yaitu frasa dan partikel. “apa kabar?” dan Deh. Ungkapan fatis apa kabar memiliki tugas untuk memulai sebuah komunikasi atau percakapan dalam situasi percakapan diatas antara Dika dan mantan. Mereka sudah tidak bertemu selama beberapa tahun, selain itu keduanya pernah ada yang menyakiti dan tersakiti maka ungkapan fatis "apa kabar" cukup untuk mengawali dan membuka percakapan keduanya. Mitra tutur juga tidak akan terlalu sulit untuk menjawabnya hanya dengan "baik" sudah cukup mewakili dan mencairkan suasana mereka. Ungkapan fatis berikutnya yaitu deh yang memiliki tugas untuk menekankan terhadap sesuatu. Pada tuturan "aku kayaknya salah deh jadian sama dia” “deh” digunakan oleh penutur yaitu mantan Dika untuk menekankan terhadap satu kondisi yang sedang dia alami dan rasakan. Sang mantan ingin mencoba menekankan sesuatu yaitu rasa sesal dan bersalah karena telah berselingkuh dan mengkhianati Dika. Melalui tuturan tersebut seolah sang mantan ingin menyatakan sesuatu lebih dari apa yang ia katakan. Hal ini terlihat dari jawaban atas pertanyaan Dika “aku menyesal”

Untuk mengukuhkan pembicaraan di telepon dan memberi salam mitra tutur yang dianggap dekat.

Halo Data 108: sore itu papah Dika menelpon Dika karena baru mengetahui bahwa anaknya baru saja selesai membuat Film cinta brontosaurus.

Dika : Halo, ada apa pa? Tumben telepon.

Papah : Hei, tadi papah di kantor liat acara gosip

Dika : Oh terus?

Papah : ternyata kau bikin film ya?judulnya ......

Dika : cinta brontosaurus pah.

Hari itu Dika telah selesai gelar gala premier untuk film terbarunya cinta brontosaurus. Dia sengaja tidak mengundang papahnya karena dia takut papahnya akan malu dan marah karena Dika memasukan omongan papahnya di kehidupan nyata saat papanya berbicara kurang sopan di meja makan dimasukan dalam penggalan film tersebut. namun di luar dugaan tiba-tiba papahnya menelpon bukan untuk marah-marah melainkan mengkritik film tersebut kurang berani karena saat adegan Dika dan pacarnya tidak ada ciuman romantis.

Ungkapan fatis dalam dialog di atas masuk ke dalam kategori jenis kata yaitu halo. Ungkapan fatis tersebut bertugas untuk mengukuhkan pembicaraan di telepon dan memberi salam kepada mitra tutur. Seperti pada tuturan Dika "halo ada apa pa? Tumben telepon, Dika menuturkan halo sebagai pengukuhan awal percakapan di telepon dan sekaligus memberi salam dalam hal ini pada ayahnya. Dalam tuturan dika tanpa basa-basi juga karena dipengaruhi oleh faktor kedekatan yaitu ayah dan anak maka cukup dengan berkata halo dan langsung bertanya tentang apa maksud mitra tutur menelponnya.
Untuk memulai interkasi atau komunikasi

Assalamualaikum, waalaikumsalam Data 107: malam itu Dika mengajak pacarnya untuk datang ke rumah dan makan malam bersama keluarganya.

$\begin{array}{ll}\text { Pacar } & \text { : Assalamualaikum } \\ \text { Mamah } & \begin{array}{l}\text { : waalaikumsalam, wah ini pati si } \\ \text { anu ya? }\end{array} \\ \text { Dika } & \begin{array}{l}\text { : Iya mah } \\ \text { Pacar }\end{array} \\ \text { Mamah } & \text { Halo tante } \\ & \text { : waduh kamu cantik sekali kayak tante } \\ & \text { waktu masih muda. }\end{array}$

Dika mengajak pacaranya kerumah untuk makan malam sekaligus dikenalkan pada kedua orang tuanya. Saat mereka sampai di rumah langsung disambut oleh mamahnya Dika dan diberi sanjungan atas kecantika sosok pacar Dika tersebut melalui tuturan waduh kamu cantik sekali kayak tante waktu masih muda. Percakapan mereka berlanjut akrab di meja makan. Mereka saling ngobrol dan tertawa bersama.

Ungkapan fatis yang ada pada dialog di atas adalah assalamualaikum dan waalaikumsalam. Tuturan fatis assalamualaikum bertugas untuk memulai interaksi dan dituturkan oleh seorang muslim. Sedangkan walaikumsalam merupakan jawaban dari mitra tutur setelah dia mendengar tuturan assalamualaikum. Pada dialog diatas pacar Dika bertutur :"Assalamualaikum” saat sebelum dibukakan pintu oleh mamahnya Dika. Lalu mamahnya Dika membukakan pintu sambil menjawab salam dengan "waalaikumsalam”. Setelah pacar dan mamahnya Dika bertemu mereka saling tersenyum dan pacar Dika menggunakan ungkapan fatis “Halo” yang berfungsi untuk memulai sebuah pembicaraann agar tidak terkesan kaku. Tuturan halo ini tidak terlalu membutuhkan jawaban halo juga atau baik namun sangat penting juga sebagai alat untuk mengakrabkan satu sama lain. Hal ini tercermin pada tuturan mamah "waduh kamu cantik sekali kayak tante waktu masih muda”. Dengan percakapan seperti itu mampu menghapus jarak antara mereka dan seolah mereka telah akrab atau sudah kenal sebelumnya.

\section{KESIMPULAN}

Ungkapan atau kategori fatis sering digunakan hampir dalam setiap tuturan lisan maupun tulisan yang sifatnya non-standar. Penggunaan ungkapan ini memiliki tujuan untuk memecahkan kesenyapan, menjaga hubungan sosial antara penutur dan mitra tuturnya. Dialog dalam buku “Koala Kumal” dari penulis muda terkenal Raditya Dika, terdapat banyak ungkapan atau kategori fatis. Dalam tulisan ini penulis telah melakukan pengamatan dan mengelompokan ungkapan fatis yang ada dalam 
buku tersebut berdasarkan kategorinya yaitu partikel, kata, dan frasa. Selain itu penulis juga melakukan pengelompokan kategori fatis berdasarkan tujuannya yaitu untuk memulai, mempertahankan, serta mengukuhkan tuturan.

Penulis memperoleh simpulan bahwa ungkapan fatis kategori partikel sangat mendominasi keberadaannya dalam dialog atau tuturan dalam buku tersebut dan memiliki tujuan untuk mengukuhkan sesuatu. Sedangkan untuk ungkapan fatis kategori kata dan frasa penulis menemukan beberapa dialog yang menggunakan "halo, assalamalaikum, terima kasih, dan apa kabar. Halo, apa kabar, assalamualaikum memiliki tujuan untuk memulai pembicaraan sedangka waalaikumsalam dan terima kasih memiliki tujuan untuk mengakhiri percakapan.

\section{REFERENSI}

Hymes, Dell. 1972. Language In Culture and Society. New York: Harper and Row
Leech. N Geoffrey. 1983. Principle of Prgamatics. Cambridge: Cambridge University Press.

Kridalaksana, Harimurti. 1999. Tata Wacana Deskriptif Bahasa Indonesia. Jakarta: Fakultas Ilmu Pengetahuan Budaya Universitas Indonesia.

Kridalaksana, Harimurti. 2008. Kelas kata dalam bahasa Indonesia. Jakarta: PT Gramedia.

Sudaryanto. 2015. Metode dan Teknis Analisis Bahasa: Pengantar Penelitian Wahana Budaya Secara Linguistik. Jogjakarta: Sanata Dharma University Press.

Sutami, Hermina, dkk. 2005. Ungkapan Fatis dalam Pelbagai Bahasa. Depok: Fakultas Ilmu Pengetahuan Budaya Universitas Indonesia. 